\title{
Prionospio thalanji sp. nov. (Polychaeta: Spionidae) from an anchialine cave, Cape Range, north-west Western Australia
}

\author{
Robin S. Wilson ${ }^{1}$ and William F. Humphreys ${ }^{2}$ \\ ${ }^{1}$ Museum Victoria, GPO Box 666E, Melbourne, Victoria 3001, Australia \\ rwilson@museum.vic.gov.au \\ ${ }^{2}$ Western Australian Museum, Francis Street, Perth, Western Australia 6000, Australia \\ bill.humphreys@museum.wa.gov.au
}

\begin{abstract}
Prionospio thalanji sp. nov., a polychaete worm of the family Spionidae, is described from a limestone cave on the Cape Range peninsula, north-west Western Australia. This is the first record of a cavernicolous spionid and is one of the few aquatic species from Cape Range caves with an immediate marine sister taxon.
\end{abstract}

\section{INTRODUCTION}

The Cape Range peninsula of north-west Western Australia abuts the Indian Ocean at $22^{\circ} \mathrm{S}$ and is largely limestone of Miocene age (Wyrwoll et al., 1993). Extensive cave systems dissect the limestone (Allen, 1993); these include terrestrial caves which harbour troglobitic arthropods dominated by arachnids and myriapods (Harvey et al., 1993; Humphreys, 2000b), and anchialine caves with a fauna of aquatic stygobiont fishes, crustaceans and a gastropod (Humphreys, 1993, 2000b).

Anchialine habitats consist of bodies of haline waters, usually with a restricted exposure to open air, always with more or less extensive subterranean connections to the sea, and showing noticeable marine as well as terrestrial influences (Stock et al., 1986). They typically occur in volcanic or limestone bedrock (Iliffe, 2000); the Cape Range region contains the only continental anchialine system described from the southern hemisphere (Iliffe, 2000). These recently recognized ecosystems are yielding an extraordinary diversity of specialised animals, especially crustacea, of which more than 12 new families and a new class have been described in recent years (G.A. Boxshall, personal communication, 1999).

This paper is the first description of annelid worms from the anchialine caves of Cape Range.

\section{MATERIALS AND METHODS}

In 1993 and 1994 samples were collected by SCUBA equipped cave divers from various depths using towed plankton nets, hand-held suction devices ('slurp gun'), nets and bottles. Suction samples at this time were from known depths, but towed net samples were of uncertain origin. The 'slurp gun' is a vigorous sampling method that resulted in damaged specimens, however, subsequent sampling using less vigorous methods (Humphreys, 1999a) has not resulted in additional polychaete material.

Annelid worms from these samples were examined and found to contain three specimens of a polychaete of the family Spionidae, which is described below as a new species. Sample BES 4294 contained a specimen in very poor condition of a different, unidentified polychaete. All specimens are housed in the Western Australian Museum, Perth.

In preparation for field emission scanning electron microsopy the holotype was rehydrated from $70 \%$ ethanol, post-fixed in $1 \%$ osmium tetroxide for $2 \mathrm{hrs}$, returned stepwise to $100 \%$ ethanol for critical point drying and sputter coating. Observations were made using a Philips XL 30 field emission scanning electron microscope (SEM). The anterior fragment of one paratype, WAM BES 4294 disintegrated when washed from a temporary slide mount and is lost, though 2 posterior fragments remain. Due to the extreme fragility of the specimens (especially branchiae), individual branchiae and parapodia were not removed and figured; their form and proportions were described from the scanning electron micrographs of the holotype.
Abbreviations
WAM: Western Australian Museum
BES: field numbers of biospeleology collection at WAM
C-numeral: Prefix for the Karst Index number denoting caves in the Cape Range karst province. 


\section{SYSTEMATICS}

\section{Family Spionidae Grube, 1850}

\section{Genus Prionospio Malmgren, 1867}

Prionospio Malmgren, 1867: 201; Blake and Kudenov, 1978: 211-212; Hutchings and Turvey, 1984: 11; Maciolek, 1985: 329-332; Wilson, 1990: 245-246.

Ctenospio M. Sars, 1867: 291.

Anaspio Chamberlin, 1920: 18.

Aquilaspio Foster, 1971: 105; Hutchings and Turvey, 1984: 8.

Minuspio Foster, 1971: 106; Hutchings and Turvey, 1984: 10-11.

\section{Prionospio thalanji sp. nov.} Figures 1-8

\section{Material examined}

\section{Holotype}

Bundera Sinkhole, Western Australia, Australia, $22^{\circ} 25^{\prime} \mathrm{S}, 113^{\circ} 46^{\prime} \mathrm{E}$, 'slurp gun', 24 May 1995, coll. A. Poole, D. Warren W.F. Humphreys, WAM V4161 (BES 4262).

\section{Paratypes}

Australia, Western Australia: 1 specimen, Bundera Sinkhole, $22^{\circ} 25^{\prime} \mathrm{S}, 113^{\circ} 46^{\prime} \mathrm{E}$, 'slurp gun', 26 May 1995, coll. A. Poole, D. Warren, W.F. Humphreys, WAM V4162 (BES 4294); 1 specimen, Bundera Sinkhole, $22^{\circ} 25^{\prime} \mathrm{S}, 113^{\circ} 46^{\prime} \mathrm{E}$, 'slurp gun', 21 March 1994, coll. A. Poole, WAM V4163 (BES 1363).

\section{Diagnosis}

Prostomium truncate anteriorly, continuing posteriorly to chaetiger 1 . Chaetiger 1 with notochaetae. Occipital antenna absent, one pair of eyes. Branchiae simple with ciliated margins, first on chaetiger 2, last on chaetiger 28-30 (probably earlier on small specimens). Dorsal crests absent. Hooded hooks absent in notopodia, hooded hooks with 6 teeth above the main fang present in neuropodia from chaetiger $60-65$. Sabre chaetae in ventral neuropodial positions from about chaetiger 20.

\section{Description}

The holotype is a complete specimen in two fragments: anterior fragment of 33 chaetigers, posterior fragment of 41 chaetigers. Total size 75 chaetigers, $10 \mathrm{~mm}$ long. $0.3 \mathrm{~mm}$ wide at chaetiger 10 , excluding parapodia. Both fragments mounted on SEM stub excepting neurochaetae from chaetigers 68 and 69 subsequently removed to permanent light microscope slide mount. Paratype WAM V4162 of 3 fragments apparently from a single specimen: anterior fragment of 16 chaetigers, $2 \mathrm{~mm}$ long, $0.2 \mathrm{~mm}$ wide at chaetiger 10 excluding parapodia; median fragment of 7 chaetigers, $1 \mathrm{~mm}$ long; posterior fragment of 11 chaetigers, $1 \mathrm{~mm}$ long. Paratype WAM V4163 of 2 fragments apparently from a nearly complete specimen: anterior fragment of 16 chaetigers, 1.5 $\mathrm{mm}$ long, $0.3 \mathrm{~mm}$ wide at chaetiger 10 excluding parapodia; posterior fragment of 20 chaetigers, 2 mm long.

Prostomium (Figures 1, 6) blunt, anteriorly truncate with entire anterior margin; frontal or lateral horns absent. Posterior prolongation of prostomium continuing back to chaetiger 1 ; free from dorsum. Palps unknown. Occipital antenna absent. Nuchal organ short, at most one segment long. One pair of eyes present as faint pigment spots (no eye structures visible under SEM). Specimen has proboscis partially everted (see figure 1); this everted structure appears almost continuous with the prostomium on the SEM which is annotated to delineate the anterior margin of the prostomium.

Dorsal branchiae free and separate from notopodial lamellae throughout; first present on chaetiger 2; last on 30. Branchiae apinnate, with ciliated margins (Figure 7). Dorsal branchiae of anterior-most chaetigers are about 2 times as long as notopodial lobe, reducing in absolute and relative size posteriorly so that by chaetiger 25 branchiae and notopodia are about equal in length. Accessory branchiae absent from posterior part of notopodium. Ventral branchiae absent.

Dorsal crests absent but anterior 22 chaetigers with a single transverse ciliated band across the dorsum of each segment (Figure 7). Chaetiger 1 with notochaetae. Notopodial lobes asymmetrical, lanceolate, neuropodial lobes about half as long as notopodial lobes throughout, both parapodial lobes reducing in size on posterior chaetigers (Figures 5, 8). Neuropodial lobe of chaetiger 2 rounded, approximately symmetrical, lacks any ventral projection and does not differ from neuoropdial lobes of adjacent chaetigers (Figure 2). Interparapodial pouches absent.

Chaetigers 2-4 similar, not strongly differentiated. Posterior modified notochaetae absent. Notopodial hooded hooks absent. Neurochaetae of chaetiger 1 simple capillaries similar to those of subsequent chaetigers. Neuropodial hooded hooks present, first on chaetiger 60-65; with 6 accessory teeth in 2 rows of 3 above the main fang; secondary tooth closely applied to the main fang, about $45^{\circ}$ (Figure 3 ). Neuropodial sabre chaetae present from chaetiger 20 or perhaps earlier and are apparently missing 

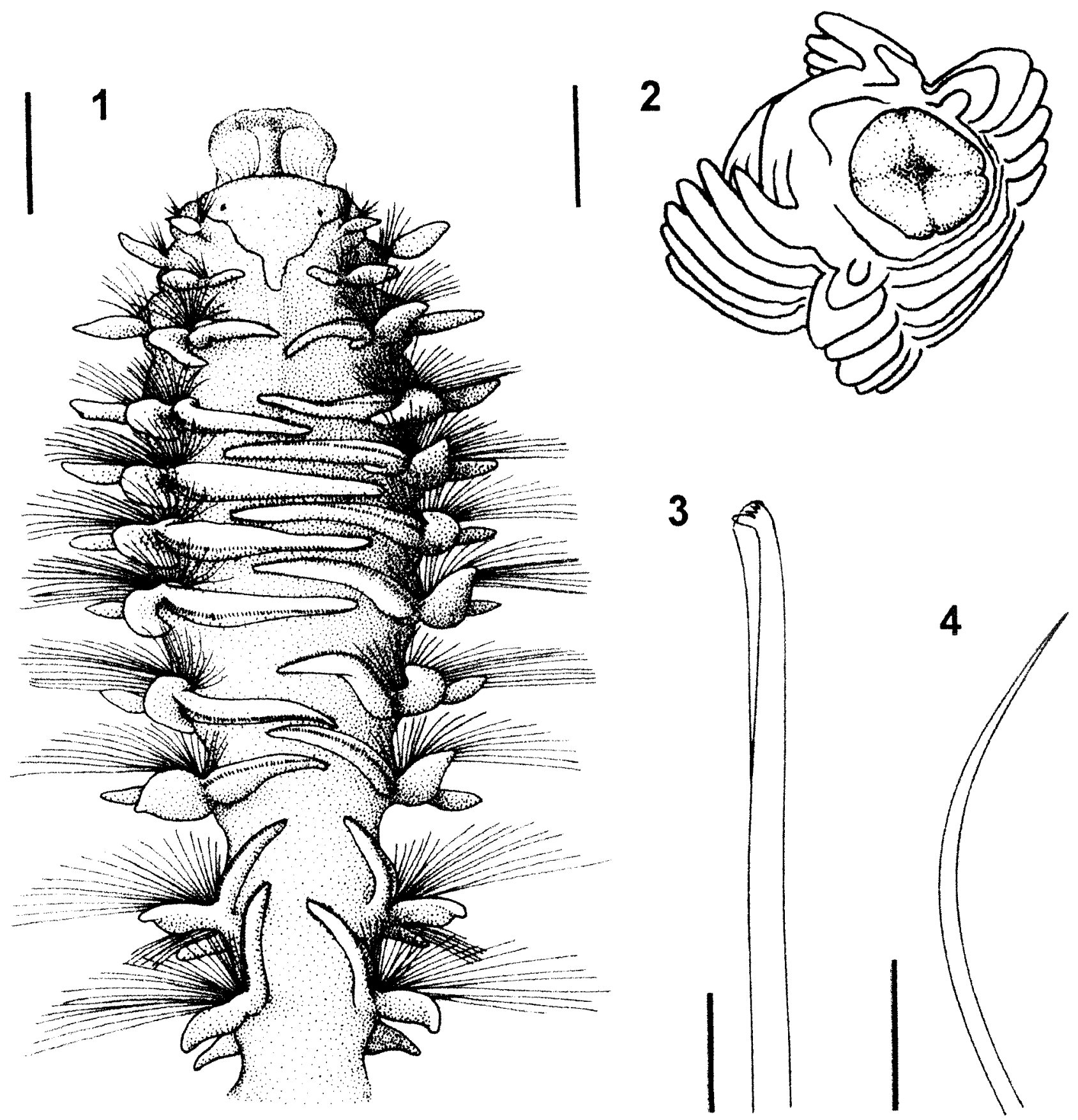

Figures 1-4 Prionospio thalanji sp. nov.: 1, holotype, dorsal view (proboscis everted; drawing made prior to preparation of SEM mount), scale $0.2 \mathrm{~mm}$; 2, paratype WAM V4163, ventro-lateral view of anterior end (proboscis everted), scale $0.2 \mathrm{~mm} ; 3$ holotype, neuropodial hooded hook, chaetiger 67 or 68 , scale $0.01 \mathrm{~mm} ; 4$, paratype WAM V4162, sabre chaeta, chaetiger 67 or 68 , scale $0.1 \mathrm{~mm}$

from many chaetigers (Figure 4). Neuropodial spines absent. Hooded hooks with hood closely applied to the head of the hooded hook and no accessory teeth visible using SEM. Neuropodia from chaetigers 68 and 69 removed from the SEM mount and figured using transmitted light (figure 3). Pygidium with paired lateral lappets and vestigial median ventral cirrus (observed prior to mounting specimen but no longer visible in SEM preparation).

\section{Variability}

The above description is based on the holotype. Both paratypes also have partly everted proboscis, both have neuropodial sabre chaetae from chaetiger 13, and both lack notopodial hooded hooks (as in the holotype). Neuropodial hooded hooks are present in both paratypes but the segment of first appearance cannot be determined; none are present on either 16 chaetiger anterior fragment. Paratype WAM BES 4294 is the smallest specimen and has 


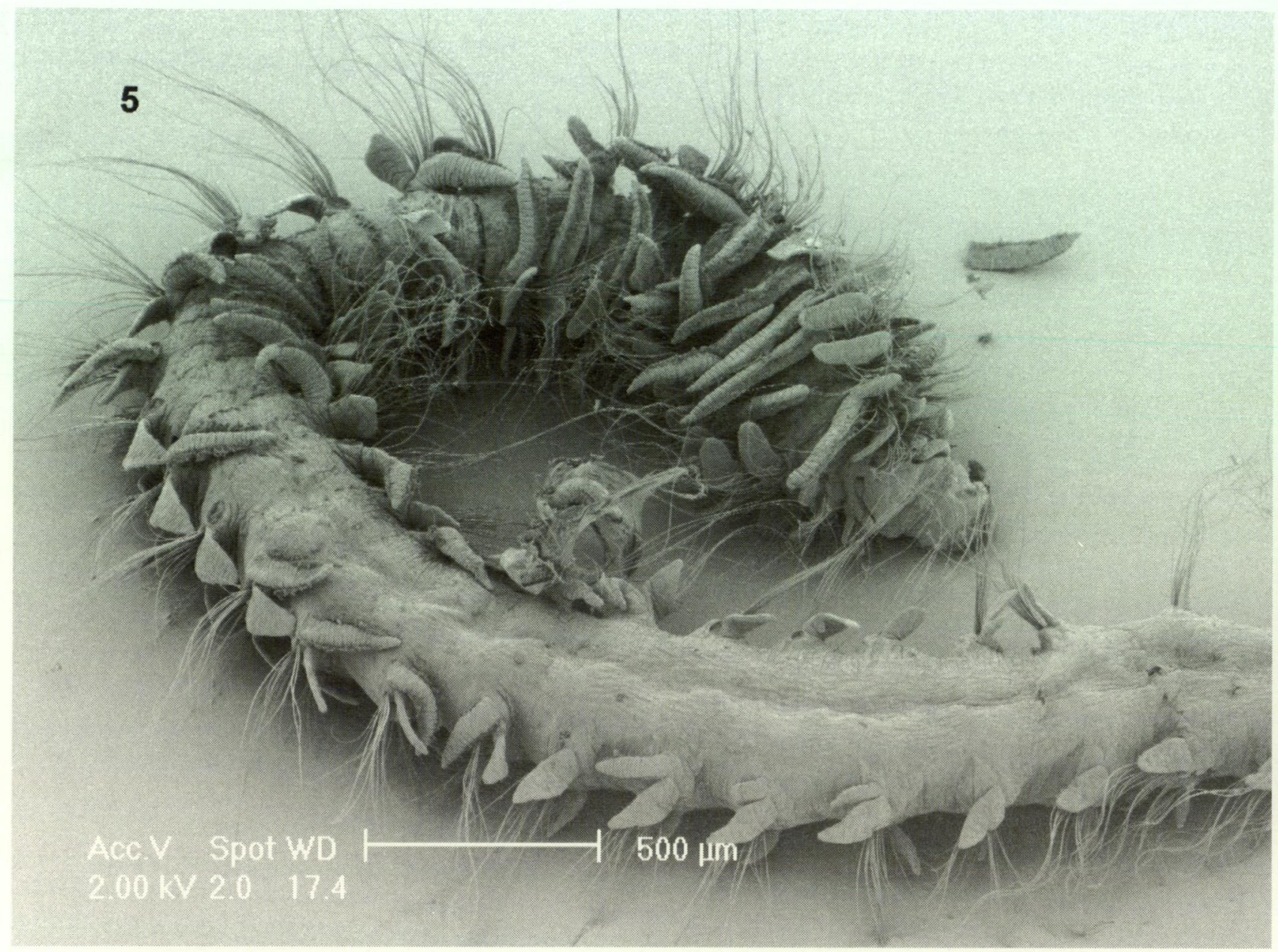

Figure 5 Prionospio thalanji sp. nov., holotype. Anterior fragment. Scale $500 \mu \mathrm{m}$.

branchiae to chaetiger 10 , however the branchiae are fragile and many appear to be lost from the specimen. Paratype WAM V4163 has branchiae to at least chaetiger 28.

\section{Comments}

The genus Prionospio has been divided into generic or subgeneric groupings as defined by different combinations of pinnate and simple branchiae (Blake and Kudenov, 1978; Maciolek, 1985; Wilson, 1990; Sigvaldadottir, 1998). Sigvaldadottir $(1997,1998)$ found it likely that these subgroups of Prionospio were artificial and did not represent monophyletic groups. Nevertheless, branchial characters remain among the most useful for distinguishing species. Prionospio thalanji is apparently most similar to other species having multiple pairs of simple, laterally ciliated branchiae. Australian species sharing these characteristics are Prionospio tatura Wilson, 1990, P. wambiri Wilson, 1990; P. yuriel Wilson, 1990. However, none of these species has more than 12 pairs of branchiae and all possess notopodial hooded hooks. If branchial number alone is taken as the best indicator of relationships among Prionospio spp., $P$. polybranchiata Fauvel, 1929 from the Gulf of Manaar, Indian Ocean, with 39 pairs of branchiae and similar hooded hooks (Maciolek, 1985) would be the most likely sister taxon to $P$. thalanji. However, there is no parsimony analysis to support this proposition. Prionospio polybranchiata is readily distinguished from $P$. thalanji by the presence of notopodial hooded hooks (absent in $P$. thalanji) and by the appearance of neuropodial hooded hooks at chaetiger 22 (they are not present until at least chaetiger 60 in $P$. thalanji). Prionospia thalanji is apparently unique in the genus in lacking notopodial hooded hooks and in the late appearance of neuropodial hooded hooks.

Prionospio thalanji is apparently the first spionid polychaete recorded from cave environments (Hartmann-Schröder, 1986). Spionids are rare in freshwater environments, although two species of Boccardia are known from coastal dune freshwater lakes in south-eastern Australia (Blake and Woodwick, 1976), and Orthoprionospio cirriformia Blake and Kudenov, 1978 is widespread in areas of reduced salinity in south-eastern Australia. 


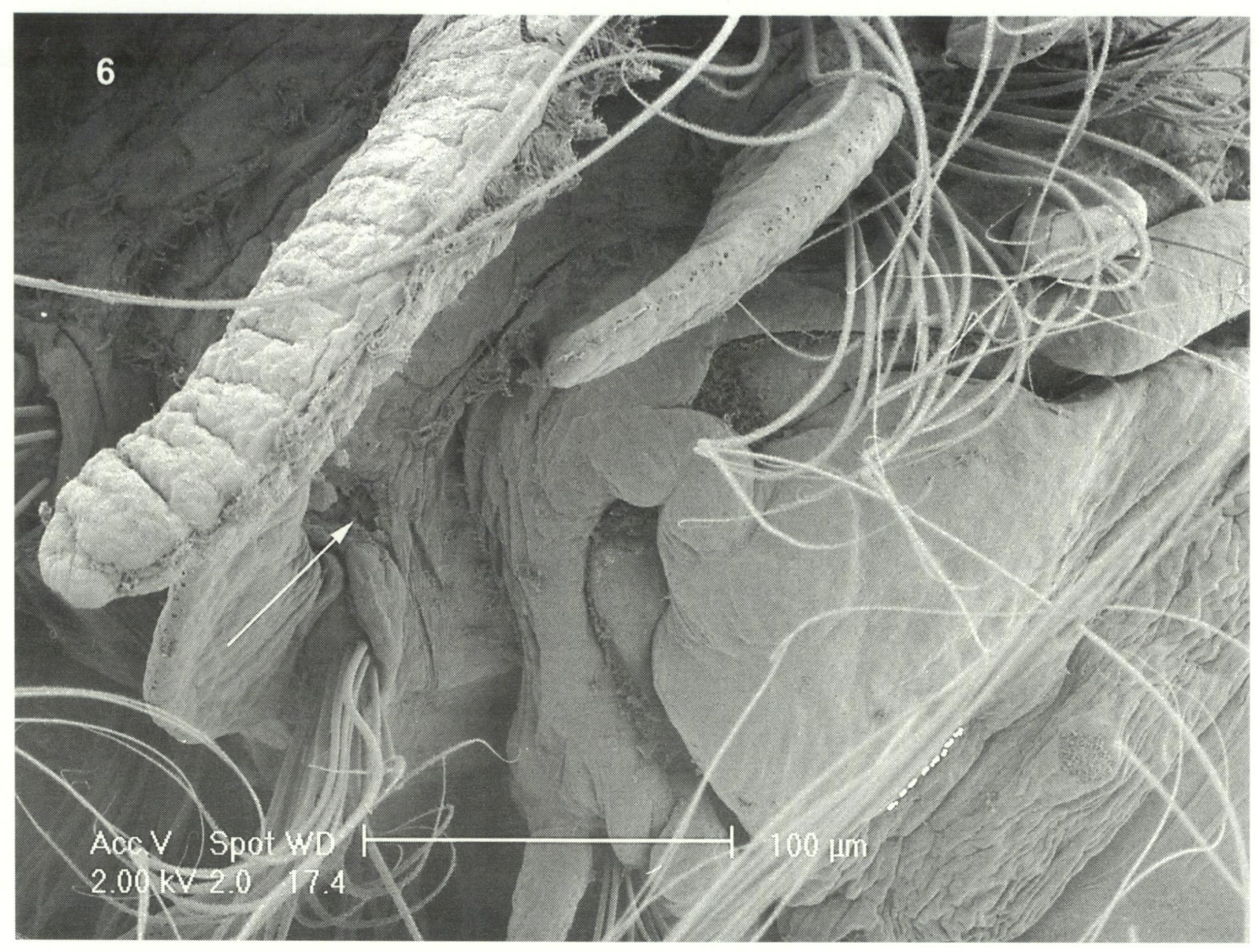

Figure 6 Prionospio thalanji sp. nov., holotype. Prostomium. Dashed line distinguishes anterior margin of prostomium from everted pharynx. Arrow indicates branchial scar on chaetiger 1. Scale $100 \mu \mathrm{m}$.

\section{Distribution}

Bundera Sinkhole, Cape Range peninsula, northwest Western Australia.

The surface salinity of Bundera Sinkhole, to the marked thermocline at a depth of about $8 \mathrm{~m}$, was about $19 \mathrm{~g} \mathrm{l}^{-1}$ TDS. An halocline between 8 and $18 \mathrm{~m}$ brings the deep salinity to about $34 \mathrm{~g} \mathrm{l}^{-1}$ and it is in this more saline water that Prionospia thalanji occurs, together with the typical anchialine fauna.

Bundera Sinkhole is the only continental anchialine system known in the southern hemisphere (Humphreys, 1999a; Humphreys et al., 1999). It is typical of an arid zone anchialine system in having brackish water overlying seawater and subject to marine tides, although situated $1.7 \mathrm{~km}$ inland. It has an especially complex physicochemical stratification, exhibiting multiple hydrogen sulphide layers, oxygen and redox minima and the characteristic signals of chemoautotrophic energy production by sulphur and nitrogen bacteria (Humphreys, 1999a). This physicochemical stratification is vulnerable to mixing disturbance by divers (Humphreys et al., 1999). This site and the regional fauna and characteristics are discussed more fully elsewhere (Poore and Humphreys, 1992; Bruce and Humphreys, 1993; Humphreys, 1993, 1999a, 2000a, 2000b; Yager and Humphreys, 1996; Humphreys et al., 1999).

\section{Etymology}

The species name thalanji is an alternative simplified spelling of the Aboriginal tribal group Thalanyji, who live in the Cape Range area.

\section{DISCUSSION}

The presence of apinnate ciliated branchiae is probably a derived condition within Prionospio, and other taxa with this condition are widely distributed in marine environments around the world (Sigvaldadóttir, 1998). The genus Prionospio is dominated by marine species, with a few estuarine representatives; none are known from truly freshwater or anchialine habitats. Thus, Prionospio thalanji is apparently a sister taxon to a marine species, though which one is unknown.

Among aquatic species so far recorded from 


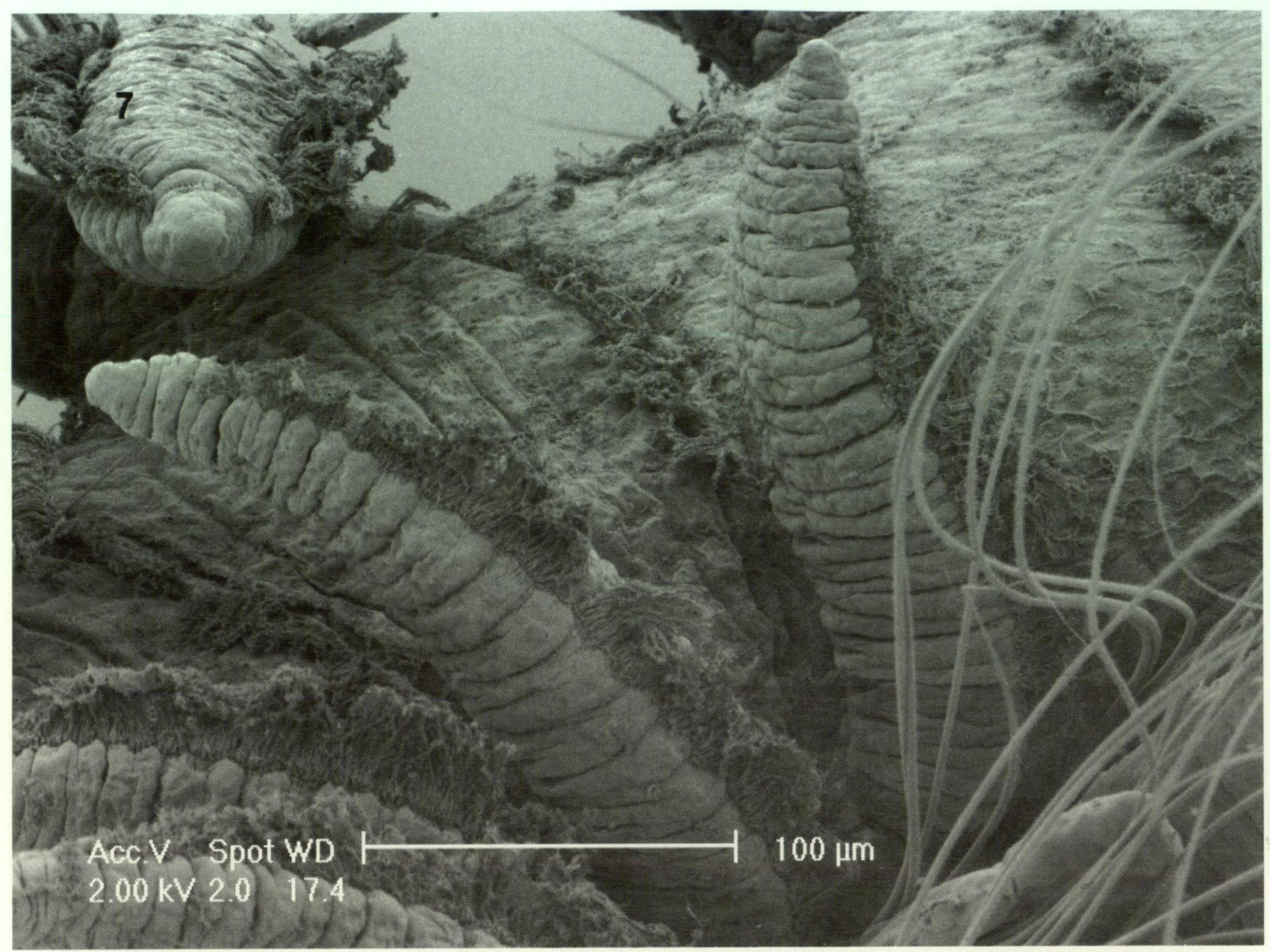

Figure 7 Prionospio thalanji sp. nov., holotype. Ciliated branchiae and ciliated transverse dorsal bands, chaetigers 10 , 11. Scale $100 \mu \mathrm{m}$.

anchialine caves of Cape Range, several have clear affinities with marine taxa: the gastropod mollusc Iravadia sp., which was recorded from the brackish part of Bundera Sinkhole, where it was exposed to full sunlight, belongs to a genus that is otherwise estuarine (Slack-Smith, 1993).

Dr G. Hartmann-Schröder determined a number of polychaetes collected from the anchialine system on the Cape Range peninsula. Sphaerosyllis centroamericana Hartmann-Schröder, 1959 (Syllidae) was also collected from Bundera Sinkhole as well as from small shallow karst windows-Tantabiddi Rockholes, C-332 (21 $\left.{ }^{\circ} 55^{\prime} \mathrm{S}, 113^{\circ} 59^{\prime} \mathrm{E}\right)$, Wobiri Rockhole, C-414 (21 50 'S, $\left.114^{\circ} 04^{\prime} \mathrm{E}\right)$ and C-506 $\left(22^{\circ} 28^{\prime} \mathrm{S}, 113^{\circ} 44^{\prime} \mathrm{E}\right)$. Specimens were also obtained from Javis Well C-362 $\left(22^{\circ} 36^{\prime} \mathrm{S}, 113^{\circ} 41^{\prime} \mathrm{E}\right)$, a deep pastoral well which also contained Typosyllis (Ehlersia) cf. broomensis Hartmann-Schröder, 1979 (Syllidae). In contrast to Prionospio thalanji, all were characterized as 'normal' marine forms.

A new species of harpacticoid copepod in the genus Phyllopodopsyllus occurs in this anchialine system at the northern end of the peninsula (Karanovic et al., in press). It is the only known occurrence of the genus outside strictly marine habitats but it displays clear stygomorphies, being colourless and lacking the nauplius eye (Karanovic et al., in press).

Other aquatic taxa known from the Cape Range anchialine cave system have their closest affinities with aquatic and/or cavernicolous taxa that are now remote from the Cape Range caves. Their affinities principally lie with the fauna from anchialine caves on either side of the North Atlantic (Humphreys, 2000b; Jaume et al., in press), and the lineages occupy the Tethyan track (Stock, 1993). In the deeper part of Bundera Sinkhole at depths between 18 and $33 \mathrm{~m}$, occurs an anchialine community, the general structure of which is predictable from the Caribbean region, the Canary Islands and northwestern Australia (e.g. Yager and Humphreys, 1996; Danielopol et al., 2000; Jaume et al., in press). It includes the genera Lasionectes (Remipedia), Danielopolina (Ostracoda: Halocyprida: Thaumatocyprididae), Liagoceradocus (Crustacea: Hadziidae), Stygiocaris (Decapoda: Atyidae), Bunderia (Calanoida: Epacteriscidae), Stygocyclopia (Calanoida: Pseudocyclopiidae) and 


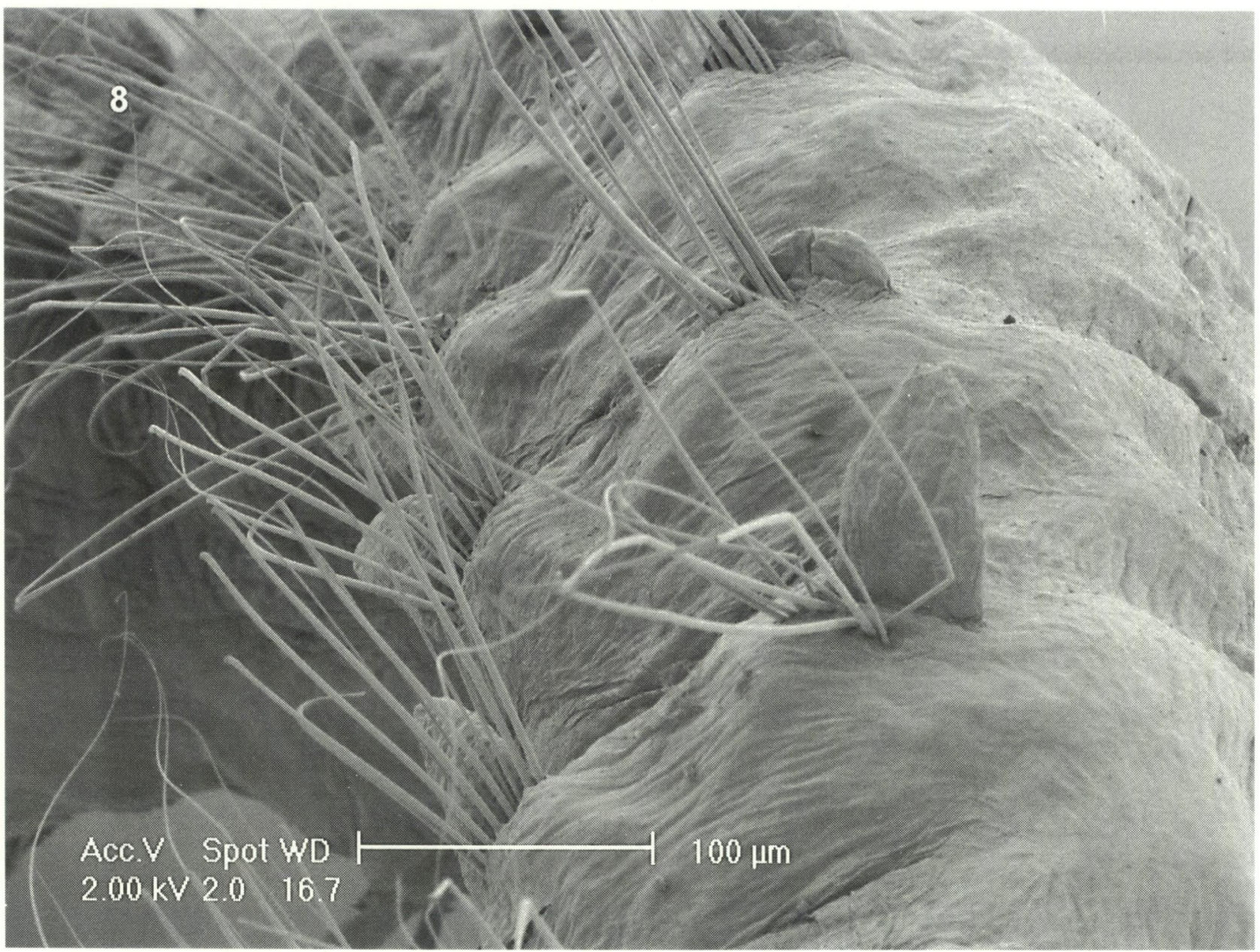

Figure 8 Prionospio thalanji sp. nov., holotype. Notopodia and neuropodia, chaetigers 50-55. Scale $100 \mu \mathrm{m}$.

Speleophria (Misophrioida: Speleophriidae). In the photic zone, above the thermohalocline, this anchialine system also contains a number of nonstygal invertebrates, including Halicyclops (Copepoda: Cyclopidae), ostracods, Iravadia sp. (Mollusca: Iravadiidae), water striders (Gerridae: Hemiptera) and Kiefferulus (Chironomidae: Diptera). A fuller description of the surface fauna associated with these karst wetlands is given elsewhere (Humphreys, 2000a, 2000b).

Elsewhere in the anchialine system of the Cape Range peninsula and Barrow Island occur other 'tethyan' taxa, including Ophisternon (Synbranchiformes: Synbranchidae), Halosbaena (Thermosbaenacea), and Haptolana (Isopoda: Cirolanidae). The gudgeon, Milyeringa (Perciformes: Eleotridae), the affinities of which are unknown, occurs throughout the anchialine system (Humphreys, 1999b, in press)

The 'tethyan' lineages probably have a long stygal history, i.e. restricted to subterranean realms, following vicariant events resulting from the movement of the tectonic plates during the Mesozoic (Humphreys, 2000b; Jaume et al., in press). No such ancient origin need be invoked to explain the presence of Prionospio thalanji and
Iravadia sp. in Cape Range caves as both have probable sister taxa that are widespread in adjacent marine environments. Molecular systematic studies that estimate times of genetic divergence between Prionospio thalanji and Iravadia sp. and their respective marine sister taxa are required to test the plausible hypothesis that these two taxa have diverged from non-cavernicolous ancestors more recently than other aquatic inhabitants of the Cape Range cave system.

\section{ACKNOWLEDGEMENTS}

Jocelyn Carpenter, then of the Electron Microscope Unit, School of Botany, University of Melbourne, went out of her way to assist with SEM preparation and examination, and Kate Nolan prepared the beautiful figure of Prionospio thalanji (Figure 1). Elin Sigvaldadóttir provided copies of her papers on spionid phylogeny. We also thank Dr G. Hartmann-Schröder who determined the Syllidae and Drs Pat Hutchings and Elin Sigvaldadóttir for their constructive criticisms of the manuscript at the review stage. This paper is a contribution to DIVERSITAS-IBOY 
project, "Exploration and Conservation of Anchialine Faunas".

\section{REFERENCES}

Allen, A.D. (1993). Outline of the geology and hydrogeology of Cape Range, Carnarvon Basin, Western Australia. Records of the Western Australian Museum, Supplement No. 45: 25-38.

Blake, J.A. and Kudenov, J.D. (1978). The Spionidae (Polychaeta) from southeastern Australia and adjacent areas with a revision of the genera. Memoirs of the National Museum of Victoria 39: 171-280.

Blake, J.A. and Woodwick, K.H. (1976). A new species of Boccardia (Polychaeta: Spionidae) from two freshwater lakes in southeastern Australia. Records of the Australian Museum 30: 123-128.

Bruce, N.L. and Humphreys, W.F. (1993). Haptolana pholeta, sp. nov., the first subterranean flabelliferan isopod crustacean (Cirolanidae) from Australia. Invertebrate Taxonomy 7: 875-884.

Chamberlin, R.V. (1920). Polychaeta, Report of the Canadian Arctic Expedition 1913-18, parasitic worms, protozoans etc. Report of the Canadian Arctic Expedition Annelids 9: 1-41.

Danielopol, D.L., Baltanás, A. and Humphreys, W.F. (2000). Danielopolina kornickeri sp. n. (Ostracoda: Thaumatocypridoidea) from a western Australian anchialine cave - morphology and evolution. Zoologica Scripta 29: 1-16.

Foster, N.M. (1971). Spionidae (Polychaeta) of the Gulf of Mexico and the Caribbean Sea. Studies on the Fauna of Curaçao and other Caribbean Islands 36: 1-183.

Hartmann-Schröder, G. (1986): Polychaeta (incl. Archiannelida): 210-233. In Botosaneanu, L. (Ed.) Stygofauna mundi. A faunistic, distributional and ecological synthesis of the world fauna inhabiting subterranean waters (including the marine interstitial). E.J. Brill, Leiden, Netherlands.

Harvey, M.S., Gray, M.R., Hunt, G.S. and Lee, D.C. (1993). The cavernicolous Arachnida and Myriapoda of Cape Range, Western Australia. Records of the Western Australian Museum, Supplement No. 45: 129144.

Humphreys, W.F. (1993). Stygofauna in semi-arid tropical Western Australia: a Tethyan connection? Mémoires de Biospéologie 20: 111-116.

Humphreys, W.F. (1999a). Physico-chemical profile and energy fixation in Bundera Sinkhole, an anchialine remiped habitat in north-western Australia. Journal of the Royal Society of Western Australia 82: 89-98.

Humphreys, W.F. (1999b). The distribution of the Australian cave fishes. Records of the Western Australian Museum 19: 469-472.

Humphreys, W.F. (2000a). Karst wetlands biodiversity and continuity through major climatic change - an example from arid tropical Western Australia: 227258 In: B. Gopal, W.J. Junk and J.A. Davis (editors), Biodiversity in wetlands: assessment, function and conservation, volume 1. Backhuys Publishers, Leiden. $353 \mathrm{p}$.

Humphreys, W.F. (2000b). Chapter 30. The hypogean fauna of the Cape Range peninsula and Barrow Island, northwestern Australia: 581-601. In: H. Wilkens, D.C. Culver and W.F. Humphreys (eds). Ecosystems of the World, vol. 30. Subterranean Ecosystems. Elsevier, Amsterdam.

Humphreys, W.F. (in press). Milyeringa veritas Whitley 1945 (Eleotridae), a remarkably versatile cave fish from the arid tropics of northwestern Australia. Environmental Biology of Fishes.

Humphreys, W.F., Poole, A., Eberhard, S.M. and Warren, D. (1999). Effects of research diving on the physicochemical profile of Bundera Sinkhole, an anchialine remiped habitat at Cape Range, Western Australia. Journal of the Royal Society of Western Australia 82: 99108.

Hutchings, P.A. and Turvey, S.P. (1984). The Spionidae of South Australia (Annelida: Polychaeta). Transactions of the Royal Society of South Australia 108: 1-20.

Iliffe, T. M. 2000. Anchialine cave ecology: 59-76. In: Wilkens, H., Culver, D.C. and Humphreys, W.F. (editors). Ecosystems of the World, vol. 30. Subterranean Ecosystems. Elsevier, Amsterdam.

Jaume, D., Boxshall, G.A. and Humphreys, W.F. (in press). New stygobiont copepods (Calanoida; Misophrioida) from Bundera sinkhole, an anchialine cenote on north-western Australia. Zoological Journal of the Linnean Society, London

Karanovic, T., Pesce, G.L. and Humphreys, W.F. (in press). Copepods from groundwaters of Western Australia, V. Phyllopodopsyllus T. Scott, 1906 in Australian anchialine waters (Crustacea: Copepoda: Harpacticoida). Records of the Western Australian Museum

Maciolek, N.J. (1985). A revision of the genus Prionospio Malmgren, with special emphasis on species from the Atlantic Ocean, and new records of species belonging to the genera Apoprionospio Foster and Paraprionospio Caullery (Polychaeta, Annelida, Spionidae). Zoological Journal of the Linnean Society. 84: 325-383.

Malmgren, A.J. (1867). Annulater polychaeta Spetsbergiae, Groenlandiae, Islandiae et Scandinaviae hactenus cognita. Öforsigt af Konglia VetenskapsAkademiens Förhandlingar, Stockholm 24: 127-235, pls215.

Poore, G.C.B. and Humphreys, W.F. (1992). First record of Thermosbaenacea (Crustacea) from the southern hemisphere: a new species from a cave in tropical Western Australia. Invertebrate Taxonomy 6: 719-725.

Sars, M. (1867). Beskrivelser og Afbildninger af norske Annelider. Forhandliger I Videnskabernes Selskab, Christiania 1866: 291.

Sigvaldadóttir, E. (1997). A new species of Prionospio (Polychaeta: Spionidae) from the Cape D'Aguilar Marine Reserve, Hong Kong: 53-61 In: Morton, B. (ed.). The Marine Flora and Fauna of Hong Kong and Southern China IV. Hong Kong University Press, Hong Kong.

Sigvaldadóttir, E.S. (1998). Cladistic analysis and classification of Prionospio and related genera (Polychaeta, Spionidae). Zoologica Scripta 27: 175-187

Slack-Smith, S.M. (1993). The non-marine molluscs of the Cape Range peninsula, Western Australia. Records of 
the Western Australian Museum, Supplement 45: 87107.

Stock, J. H. (1993). Some remarkable distribution patterns in stygobiont Amphipoda. Joumal of Natural History 27: $807-819$

Stock, J.H., Iliffe, T.M and Williams, D. (1986). The concept 'anchialine' reconsidered. Stygologia 2: 90-92.

Wilson, R.S. (1990). Prionospio and Paraprionospio (Polychaeta: Spionidae) from southern Australia. Memoirs of the Museum of Victoria 50: 243-274.

Wyrwoll, K.-H., Kendrick, G.W. and Long, J.A. (1993). The geomorphology and Late Cenozoic geomorphological evolution of the Cape Range Exmouth Gulf region. Records of the Western Australian Museum, Supplement No. 45: 1-24.

Yager, J. and Humphreys, W. F. (1996). Lasionectes exleyi, $\mathrm{sp}$. nov, the first remipede crustacean recorded from Australia and the Indian Ocean, with a key to the world species. Invertebrate Taxonomy 10: 171-187.

Manuscript received 14 November 2000; accepted 8 March 2001 .

Edited by M.S. Harvey. 